\title{
PENGARUH PENAMBAHAN TEPUNG DAUN KELOR (Moringa oleifera Lamk) TERHADAP KADAR $\beta$-KAROTEN DAN ORGANOLEPTIK BAKSO IKAN PATIN (Pangasius pangasius)
}

\author{
Oktavia Cahyaningati* dan Titik Dwi Sulistiyati \\ Teknologi Hasil Perikanan, Fakultas Perikanan dan Ilmu Kelautan, Universitas Brawijaya \\ Jl. Veteran Malang, Indonesia \\ *Koresponden penulis: oktaviacahyaningati09@gmail.com
}

\begin{abstract}
Abstrak
Bakso merupakan produk olah yang umumnya terbuat dari daging sapi, ayam atau ikan yang dilumat dan kemudian dicampur oleh beberapa bumbu untuk meningkatkan cita rasa. Salah satu daging ikan yang dapat digunakan dalam pembuatan bakso adalah daging ikan patin. Pada pembuatan bakso ikan dilakukan dengan cara menggiling daging ikan dan menambah pati beserta bumbu untuk menambah cita rasa serta penambahan bahan lain yang diijinkan. Adanya penambahan dari bahan tambahan tersebut dapat menambah kandungan gizi atau memperbaiki karakteristik bakso. Salah satunya adalah dengan penambahan tepung daun kelor pada bakso ikan patin. Tujuan dari penelitian ini untuk mengetahui pengaruh dari penambahan tepung daun kelor terhadap kadar $\beta$-karoten, organoleptik pada bakso ikan dan mengetahui jumlah penambahan tepung daun kelor terbaik pada bakso ikan patin. Metode yang digunakan adalah metode eksperimen. Rancangan percobaan yang digunakan adalah RAL (Rancangan Acak Lengkap) sederhana dengan 4 perlakuan dan 5 kali ulangan. Data yang diperoleh dianalis menggunakan ANOVA (Analysis of Variance) dan uji lanjut Tukey. Parameter organoleptik dianalisis menggunakan metode Kruskal-Wallis. Penentuan perlakuan terbaik menggunakan metode de Garmo. Hasil penelitian menunjukkan penambahan tepung daun kelor pada bakso ikan patin berpengaruh nyata $(\mathrm{p}<0.05)$ pada kadar $\beta$-karoten dan organoleptik (kenampakan, tekstur, aroma dan rasa). Penambahan tepung daun kelor terbaik pada bakso ikan patin diperoleh pada perlakuan B yaitu sebanyak $2.5 \%$. Dimana nilai dari $\beta$-karoten sebesar $2941.44 \mu \mathrm{g} / 100 \mathrm{~g}$, serta kandungan karbohidrat 23.66\%, protein 7.71\%, lemak $0.85 \%$, abu $1.79 \%$ dan nilai kadar air sebesar $61.124 \%$. Nilai organoleptik uji hedonik diperoleh kenampakan 3.22, tekstur 3.35, aroma 3.2, rasa 3.3.
\end{abstract}

Kata kunci: bakso, tepung daun kelor, $\beta$-karoten

\section{PENDAHULUAN}

Bakso merupakan produk olahan yang umumnya terbuat dari daging sapi, ayam atau ikan yang dilumat dan kemudian dicampur dengan bumbu untuk meningkatkan cita rasa. Selain itu juga ditambahkan dengan tepung tapioka sebagai pengisi dan selanjutnya dibentuk bola-bola dimasukkan ke dalam air mendidih. Bakso selain memiliki kandungan protein yang tinggi juga memiliki cita rasa yang khas dan enak [1]. Bakso ikan memiliki kandungan protein yang cukup tinggi jika dibandingkan dengan bakso sapi dimana bakso ikan memiliki kandungan protein sebesar 46.95\%[2] sedangkan bakso sapi memiliki kandungan protein sebesar 44.95\%[3]. Salah satu jenis daging ikan yang dapat digunakan untuk pembuatan bakso adalah daging ikan patin.
Pada pembuaatan bakso ikan dilakukan dengan mecampurkan daging ikan yang telah dihaluskan kemudian digiling (kadar ikan $50 \%$ ) dan ditambahkan pati atau serealia beserta bumbu-bumbu untuk menambah cita rasa dengan atau penambahan bahan-bahan kimia serta bahan tambahan yang diijinkan. Bahan-bahan yang ditambahkan tersebut tidak memiliki sifat yang berbahaya jika di konsumsi. Selain itu juga dengan penambahan bahan tambahan tersebut dapat menambah kandungan gizi atau memperbaiki karakteristik dari bakso[4]. Salah satunya adalah dengan menambahkan tepung daun kelor dengan tujuan untuk memperkaya kandungan gizi pada bakso ikan.

Tepung daun kelor ini salah satu bentuk pemanfaatan dari tanaman kelor yang banyak tumbuh di Indonesia. Tanaman kelor merupakan tanaman yang sudah dikenal luas 
oleh masyarakat Indonesia. Namun pemanfaatan dari tanaman kelor ini belum maksimal. Dimana tanaman kelor ini banyak ditanam sebagai pagar hidup yang ditanam disepanjang ladang atau tepi sawah berfungsi sebagai tanaman penghijau[5]. Namun masyarakat juga mengonsumsi daun kelor sebagai sayuran dan juga makanan yang berkhasiat. Kelor sendiri merupakan tanaman yang memiliki nilai gizi yang tinggi. Setiap bagian dari tanaman kelor memiliki kandungan yang sangat penting seperti mineral, protein, $\beta$ karoten, asam amino, vitamin $\mathrm{C}$ dan juga Vitamin E sebagai antioksidan. Salah satu bagian yang dapat dimanfaatkan pada tanaman kelor adalah bagian daunnya. Daun kelor memiliki kandungan $\beta$-karoten sebesar 6.80 mg dalam kondisi segar[6], sedangkan dalam bentuk tepung memiliki kandungan $\beta$-karoten sebesar $16.3 \mathrm{mg}[7]$.

Pada umumnya bakso yang terdapat dipasaran tidak mengandung vitamin $A$ atau $\beta$ karoten di dalamnya[8]. Sehingga dengan adanya penambahan tepung daun kelor pada bakso ikan patin diharapkan dapat memperkaya kandungan gizi pada bakso salah satunya yaitu kandungan $\beta$-karoten. $\beta$-karoten merupakan salah satu jenis dari pigmen yang larut dalam lemak yaitu karotenoid. $\beta$-karoten adalah bentuk provitamin A yang paling aktif. Karotenoid termasuk juga $\beta$-karoten memiliki sifat fungsional sebagai antioksidan, mencegah penyakit rabun senja, penyakit kanker terutama kanker paru-paru[9]. Selain itu $\beta$-karoten yang merupakan provitamin A memiliki fungsi fisiologis pada tubuh seperti fungsi penglihatan, diferensiasi sel, imunitas tubuh, pertumbuhan dan perkembangan serta reproduksi[10].

\section{METODOLOGI}

Alat-alat yang dibutuhkan dalam penelitian ini adalah sebagai berikut, pertama alat yang digunakan dalam pembuatan bakso ikan patin adalah pisau, sendok, garbu, talenan, spatula, peniris, serbet, timbangan, baskom, cooper, blender, panci, kompor, oven, loyang, blender dan ayakan (mesh size 100). Bahanbahan yang digunakan dalam pembuatan bakso ikan patin adalah sebagai bagai berikut, ikan patin segar (dengan ciri masih berbau segar khas ikan, bola mata masih menonjol dan cerah, insang merah cemerlang dan tidak berlendir, tekstur daging masih padat dan kenyal)[11], tepung tapioka, garam, lada, bawang putih, bawang merah dan air dingin dan es batu yang di beli di pasar Mergan, Kota Malang. Bahan yang digunakan dalam pembuatan tepung daun kelor adalah daun kelor yang didapat di Desa Mandesa Kabupaten Blitar.

Metode penelitian yang digunakan dalam penelitian ini adalah metode eksperimen, hal ini bertujuan untuk mengetahui adanya pengaruh dari perbedaan konsentrasi tepung daun kelor yang ditambahkan pada bakso ikan terhadapap kadar $\beta$-karoten dan organoleptik. Metode yang digunakan dalam pembuatan tepung daun kelor adalah metode blanching[12] dengan salah satu perlakuan menggunakan metode blanching kukus, kemudian dikeringakan dan digiling menjadi tepuk. Karakteristik kimia dari tepung daun kelor dapat dilihat pada Tabel 1. Sedangkan untuk metode pembuatan bakso menggunakan metode modifikasi[13] dimana pada penelitian menggunakan konsentrasi $0 \%, 2.5 \%, 5 \%$ dan 7.5\%. Parameter yang diuji dalam penelitian ini adalah kadar $\beta$-karoten dengan metode spektrofotometri, sedangkan untuk parameter organoleptik menggunakan uji hedonik meliputi kenampakan, tekstur, aroma dan rasa dengan nilai kesukaan konsumen 1-4 $(1=$ sangat tidak suka, $2=$ tidak suka, $3=$ suka, $4=$ sangat suka) dan menggunakan 40 panelis tidak terlatih.

Rancangan Percobaan dalam penelitian utama adalah Rancangan Acak Lengkap (RAL) sederhana dengan menggunakan 4 perlakuan dan 5 kali ulangan. Data hasil uji kadar $\beta$-karoten dianalisis sidik ragam menggunakan SPSS versi 16.0 untuk mengetahui pengaruh perlakuan terhadap beberapa parameter uji. Jika nilai signifikansi $<0,05$ maka perlakuan tersebut berbeda nyata. Data hasil uji kadar $\beta$-karoten dianalisis menggunakan ANOVA, jika hasil dari ANOVA berbeda nyata maka dilanjutkan dengan uji Tukey. Data hasil uji organoleptik dianalisis Kruskal-Wallis. Perlakuan Bakso ikan patin terbaik ditentukan menggunakan metode de garmo. 
Tabel 1. Karakteristik kimia dari tepung daun kelor

\begin{tabular}{ccc}
\hline Komponen & $\begin{array}{c}\text { Tepung Daun } \\
\text { Kelor* }\end{array}$ & $\begin{array}{c}\text { Tepung Daun } \\
\text { Kelor }^{[25]}\end{array}$ \\
\hline Karbohidrat (\%) & 59.40 & 51,59 \\
Protein (\%) & 17.20 & 23.37 \\
Lemak (\%) & 4.79 & 6.74 \\
Abu (\%) & 10.46 & 11.67 \\
Air (\%) & 8.15 & 6.64 \\
$\beta$-karoten & & \\
(mg/100g) & $253.565^{* *}$ & $16.3^{[6]}$ \\
\hline
\end{tabular}

* Laboratorium Pengujian Mutu Dan Keamanan Pangan, Jurusan Teknologi Hasil Pertanian, Fakultas Teknologi Pertanian, Universitas Brawijaya, Malang

**Laboratorium Chem-Mix Pratama, Bantul, Yogjakarta

\section{HASIL DAN PEMBAHASAN}

\section{Kadar $\beta$-karoten}

Hasil analisis $\beta$-karoten pada bakso ikan patin dengan penambahan tepung daun kelor dapat dilihat pada Gambar 1.

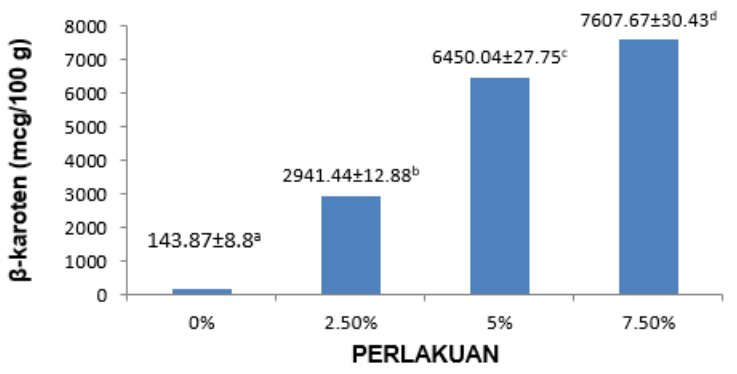

Gambar 1. Grafik Kadar $\beta$-karoten Penambahan Tepung Daun Kelor pada Bakso Ikan Patin

Berdasarkan Gambar 1 diatas menunjukkan hasil analisis ANOVA kadar $\beta$ karoten penambahan tepung daun kelor pada bakso ikan patin menunjukkan berbeda nyata $(\mathrm{p}<0.05)$. Dimana dapat dikatakan bahwa perlakuan penambahan dari tepung daun kelor dapat menambah kadar $\beta$-karoten pada bakso ikan patin. Selajutnya hasil tersebut diuji dengan uji lannjut yaitu uji lanjut Tukey dimana hasilnya menunjukkan bahwa semua perlakuan berbeda nyata. Dari Gambar 1 dapat dilihat bahwa kadar $\beta$-karoten tertinggi didapatkan pada perlakuan D $(7.5 \%)$ sebesar $7607.67 \mathrm{mcg} \pm 30.43$ dan terendah didapatkan pada perlakuan A $(0 \%)$ sebesar $143.87 \mu \mathrm{g} \pm$ 8.8 .

Dari hasil diatas menunjukkan bahwa penambahan dari tepung daun kelor pada bakso ikan patin memberikan pengaruh terhadap kandungan dari $\beta$-karoten. Hal ini dipengaruhi oleh kandungan $\beta$-karoten pada tepung daun kelor dimana semakin banyak penambahan dari tepung daun kelor pada bakso ikan patin maka akan menambah juga kadar $\beta$-karoten dari bakso ikan patin. Kandungan $\beta$-karoten yang dimiliki oleh tepung daun kelor adalah sebesar $16.3 \mathrm{mg} / 100 \mathrm{~g}[6]$. Selain kandungan $\beta$-karoten di dalam tepung daun kelor, kadar $\beta$ karoten pada bakso ikan patin juga didapatkan pada bahan tambahan yang digunakan dalam pembuatan bakso ikan patin. Seperti kandungan $\beta$-karoten pada bawang putih sedikit mengandung $\beta$-karoten yaitu $0.01 \mu \mathrm{g}$, bawang merah sebesar $2.1 \mu \mathrm{g}[14]$ dan lada sebesar $156 \mathrm{mcg} / 100 \mathrm{~g}^{[15]}$.

\section{Karakteristik Organoleptik}

Pada penelitian utama ini menggunakan 40 panelis dalam menentukan karakteristik organoleptik penambahan tepung daun kelor pada bakso ikan patin. Hasil dari karakteristik organoleptik hedonik penambahan tepung daun kelor pada bakso ikan patin dapat dilihat pada Tabel 2.

Tabel 2. Karakteristik Organoleptik Hedonik Penambahan Tepung Daun Kelor pada Bakso Ikan Patin

\begin{tabular}{ccccc}
\hline Perlakuan & $\begin{array}{c}\text { Kenam- } \\
\text { pakan }\end{array}$ & Aroma & Tekstur & Rasa \\
\hline A & $3.07 \pm 0.89 \mathrm{a}$ & $3.1 \pm 0.67 \mathrm{a}$ & $3.22 \pm 0.7 \mathrm{a}$ & $3.15 \pm 0.73 \mathrm{a}$ \\
$\mathrm{B}$ & $3.22 \pm 0.77 \mathrm{a}$ & $3.2 \pm 0.65 \mathrm{a}$ & $3.35 \pm 0.62 \mathrm{a}$ & $3.3 \pm 0.76 \mathrm{a}$ \\
$\mathrm{C}$ & $2.77 \pm 0.89 \mathrm{~b}$ & $2.7 \pm 0.76 \mathrm{~b}$ & $2.87 \pm 0.88 \mathrm{~b}$ & $2.52 \pm 0.96 \mathrm{~b}$ \\
D & $2.57 \pm 0.84 \mathrm{~b}$ & $2.57 \pm 0.7 \mathrm{~b}$ & $2.85 \pm 0.66 \mathrm{~b}$ & $2.42 \pm 0.84 \mathrm{~b}$ \\
\hline
\end{tabular}

Skala: 1 (sangat tidak suka), 2 (tidak suka), 3 (suka), 4 (sangat suka)

\section{Kenampakan}

Berdasarkan hasil analis uji KruskalWallis pada hedonik kenampakan didapatkan bahwa penambahan tepung daun kelor pada bakso ikan patin berbeda nyata $(p<0.05)$. Hal ini menunjukkan bahwa penambahan tepung daun kelor berpengaruh pada kenampakan bakso ikan patin. Pada Tabel 2 menunjukkan bahwa nilai rata-rata hedonik kenampakan yang paling tinggi pada perlakuan B $(2.5 \%)$ sebesar $(3.225 \pm 0.77)$ dan nilai rata-rata terendah dari hedonik kenampakan didapatkan pada perlakuan D (7.5\%) sebesar $(2.57 \pm 0.84)$. Hal ini menunjukan bahwa panelis menyukai kenapakan bakso ikan dengan penambahan tepung daun kelor pada perlakuan B $(2.5 \%)$ 
sedangkan semakin banyak konsentrasi tepung daun kelor yang ditambahkan panelis tidak menyukai kenampakannya. Karena semakin banyak konsentrasi tepung daun kelor yang ditambahkan pada bakso ikan patin akan memberikan warna hijau pekat atau hijau tua yang dipengaruhi oleh warna dari tepung dau kelor sendiri yaitu warna hijau. Sehingga panelis lebih menyukai kenampakan pada bakso ikan patin dengan konsentrasi penambahan tepung daun kelor yang paling rendah dikarenakan di pasaran atau pada umumnya bakso ikan memiliki warna putih.

Warna yang dimiliki oleh daun kelor adalah hijau sehingga produk yang biasanya memiliki warna putih berubah menjadi warna hijau, sehingga dapat dinyatakan bahwa semakin tinggi konsentrasi penambahan tepung daun kelor pada suatu produk maka warnanya akan menjadi warna hijau pekat[16]. Sehingga panelis memilih lebih suka pada produk dengan penambahan tepung daun kelor paling rendah, dikarenakan produk yang biasanya mereka temui memiliki warna putih. Selain itu warna hijau dari daun kelor disebabkan oleh adanya kandungan klorifil yang tinggi yaitu sebesar $6890 \mathrm{mg} / \mathrm{kg}$ [17]. Kelor sendiri memiliki kandungan klorofil 4 kali lebih banyak dibandingkan dengan wheatgrass. Maka dari itu warna hijau yang ada pada tepung daun kelor dapat memberikan pengaruh kenampakan pada produk[17].

\section{Aroma}

Hasil dari penambahan tepung daun kelor pada bakso ikan patin yang telah dianalis menggunakan uji Kruskal-Wallis dan disajikan pada Tabel 1 pada parameter aroma menunjukkan berbeda nyata $(p<0.05)$. Hal ini menunjukkan bahwa adanya pengaruh aroma pada bakso ikan patin yang ditambahkan dengan tepung daun kelor. Nilai rata-rata yang didapatkan pada hedonik aroma paling tinggi diperoleh oleh perlakuan B (2.5\%) sebesar $3.2 \pm 0.65$. sedangkan nilai rata-rata hedonik aroma terendah diperoleh pada perlakuan $\mathrm{D}$ (7.5\%) yaitu sebesar $2.57 \pm 0.71$. Hasil tersebut menunjukkan bahwa perlakuan B $(2.5 \%)$ merupakan perlakuan yang paling disukai oleh panelis. Karena diduga panelis lebih menyukai aroma yang masih khas bakso ikan pada umumnya. Selain itu pada perlakuan D (7.5\%) merupakan perlakuan yang tidak disukai oleh panelis, karena semakin banyak penambahan tepung daun kelor akan bertambah juga bau atau aroma khas dari daun kelor itu sendiri. Dimana aroma tersebut kurang begitu disukai oleh panelis. Karena pada daun kelor memiliki aroma yang khas. Sehingga ketika suatu produk makanan yang ditambahkan dengan tepung daun kelor akan memiliki aroma khas dari daun kelor itu sendiri.

Daun kelor memiliki aroma yang khas dimana hal tersebut dapat mepengaruhi aroma pada produk yang diberi tambahan daun kelor atau tepung daun kelor. Sehingga bau langu pada daun kelor sendiri dapat mempengaruhi daya terima panelis pada produk. Maka dari itu semakin banyak pemberian konsentrasi tepung daun kelor pada produk aroma langu daun kelor pada produk semakin tercium baunya[18]. Selain itu juga aroma langu pada daun kelor disebabkan oleh kandungan enzim lipoksidase yang terkandung pada daun kelor $^{[19]}$. Enzim ini terdapat pada sayuran hijau karena enzim lipoksidase ini menghidrolisis atau mengurai lemak menjadi senyawasenyawa penyebab bau langu tersebut, yang tergolong pada kelompok heksanal 7 dan heksanol [19].

\section{Tekstur}

Hasil dari analisis Kruskal-Wallis hedonik tekstur penambahan tepung daun kelor pada bakso ikan patin menyatakan berbeda nyata $(\mathrm{p}<0.05)$. Hal ini menunjukkan bahwa penambahan tepung daun kelor pada bakso ikan patin berpengaruh pada tekstur bakso ikan patin. Pada grafik hedonic tekstur didapat kan hasil nilai rata-rata tertinggi pada perlakuan $\mathrm{B}$ $(2.5 \%)$ sebesar $3.35 \pm 0.62$ dan untuk nilai ratarata terendah diperoleh oleh perlakuan D $(7.5 \%)$ sebesar 2.85 \pm 0.66 . Karena semakin banyak penambahan dari tepung daun kelor akan menambah keompakan, kepadatan dan kekenyalan dari bakso ikan patin.

Penambahan daun kelor pada produk akan memiliki tekstur yang keras, semakin banyak penambahan tepung maka semakin banyak air yang bereaksi dengan tepung dan membentuk gel [20]. Maka akan menghasilkan tekstur pada produk menjadi keras. Maka semakin banyak tepung daun kelor yang ditambahkan pada adonan maka adonan semakin padat [5]. Selain itu juga hal ini dapat dipengaruhi oleh penurunan kadar akibat peningkatan suhu pada 
saat proses perebusan. Dimana kadar air yang tersebut akan menguap [21].

\section{Rasa}

Hasil dari penambahan tepung daun kelor pada bakso ikan patin dilihat dari analisis Kruskal-Wallis menyatakan berbeda nyata $(\mathrm{p}<0.05)$. Sehingga dapat dinyatakan bahwa penambahan tepung daun kelor berpengaruh terhadap rasa dari bakso ikan patin. Dari hasil grafik hedonik rasa didapatkan hasil nilai ratarata tertinggi adalah perlakuan B $(2.5 \%)$ sebesar 3.3 \pm 0.76 . hasil nilai rata-rata terendah didapatkan pada perlakuan D $(7.5 \%)$ sebesar 2.42 \pm 0.84 . Maka dapat dinyatakan bahwa perlakuan yang lebih disukai oleh panelis adalah perlakuan B $(2.5 \%)$ dimana memiliki nilai rata-rata tertinggi jika dibandingkan perlakuan yang lain yaitu sebesar $3.3 \pm 0.76$ sedangkan perlakuan yang tidak disukai oleh panelis adalah perlakuan D (7.5\%) karena memiliki nilai rata-rata terendah yaitu $2.42 \pm 0.84$. Hal ini diduga karena semakin banyak penambahan tepung daun kelor maka semakin terasa rasa dari daun kelor tersebut. Karena jika tepung daun kelor ditambahkan ke dalam produk akan memberikan sedikit rasa pahit.

Produk yang diberi tambahan tepung daun kelor memiliki rasa yang pahit. Rasa pahit dari tepung daun kelor ini dikarenakan terdapat senyawa fenol dan alkaloid [22]. Sehingga semakin banyak penambahan tepung daun kelor maka rasa pahit dari daun kelor semakin kuat. Maka semakin banyak penambahan tepung daun kelor pada produk makanan maka akan menimbulkan rasa pahit, selain itu juga warna hijau yang ditimbulkan membuat perbedaan yang terlihat jelas [5]. Rasa pahit yang terdapat pada daun kelor inilah yang menyebabkan rendahnya daya terima dari panelis.

\section{Perlakuan Terbaik}

Hasil dari beberapa parameter yaitu organoleptik, fisika (tekstur) dan kimia (air dan $\beta$-karoten) telah didapat perlakuan terbaik dari penambahan tepung daun kelor pada bakso ikan patin. Penentuan dari perlakuan terbaik ini menggunakan cara de Garmo. Hasil dari perhitungan de garmo di peroleh perlakuan terbaik pada penambahan tepung daun kelor sebanyak $2.5 \%$ pada bakso ikan patin. Hasil analisis uji perlakuan terbaik dapat dilihat pada Tabel 3.

Tabel 3. Hasil Uji Perlakuan Penambahan Tepung Terbaik Pada Bakso Ikan Patin

\begin{tabular}{lcc}
\hline \multicolumn{1}{c}{ Komponen } & $\begin{array}{c}\text { Bakso Ikan } \\
\text { Penambahan Kelor }\end{array}$ & $\begin{array}{c}\text { Bakso } \\
\text { Ikan }^{[23]}\end{array}$ \\
\hline Karbohidrat (\%) & 23.66 & - \\
Protein (\%) & 7.71 & Min. 7 \\
Lemak (\%) & 0.85 & - \\
Abu (\%) & 1.79 & Maks 2.0 \\
Air (\%) & 61.29 & Maks 65 \\
$\beta$-karoten(mcg/100g) & 2941.44 & - \\
Hedonik & & \\
Kenampakan & 3.225 & - \\
Hedonik Aroma & 3.2 & - \\
Hedonik Tekstur & 3.35 & - \\
Hedonik Rasa & 3.3 & - \\
\hline
\end{tabular}

Hasil pada Tabel 3 memiliki nilai darikandungan karbohidrat $23.66 \%$, protein $7.71 \%$, lemak $0.85 \%$, abu $1.79 \%$ dan nilai kadar air sebesar $61.124 \%$ dimana kandungan ini masih termasuk kedalam standar mutu dari bakso ikan yaitu SNI 7266:2014. Selanjutnya nilai dari kadar $\beta$-karoten sebesar 2941.44 $\mathrm{mcg} / 100 \mathrm{~g}$ dilihat dari nilai tersebut dengan mengonsumsi 1 butir bakso ikan patin ini dapat memenuhi kebutuhan $\beta$-karoten per hari. Dimana dalam 1 butir bakso ikan patin dengan penambahan tepung daun kelor memiliki berat rata-rata $20 \mathrm{~g}$, sehingga memiliki kandungan $\beta$ karoten sebanyak 59,128 mg. Karena Batas maksimum konsumsi $\beta$-karoten per hari menurut Keputusan Kepala Badan Pengawasan Obat dan Makanan RI Nomor HK.00.05.23.3644 adalah $15 \mathrm{mg} / \mathrm{hari}$. Nilai organoleptik dengan uji hedonik diperoleh kenampakan 3.225, tekstur 3.35, aroma 3.2, rasa 3.3 .

\section{KESIMPULAN}

Kesimpulan yang dapat diambil dalam penelitian ini adalah penambahan tepung daun kelor pada bakso ikan patin memiliki pengaruh nyata $(\mathrm{p}<0.05)$ pada kadar $\beta$-karoten dan organoleptik (kenampakan, tekstur, rasa dan aroma). Penambahan tepung daun kelor terbaik pada bakso ikan patin didapatkan pada perlakuan B (2.5\% penambahan tepung daun kelor) dengan nilai kadar $\beta$-karoten sebesar $2941.44 \mathrm{mcg} / 100 \mathrm{~g}$, tekstur $24.86 \mathrm{~N}$ dan nilai kadar air sebesar $61.124 \%$. Serta kandungan karbohidrat $23.66 \%$, protein $7.71 \%$, lemak 
$0.85 \%$ dan abu $1.79 \%$, dimana kandungan ini masih termasuk kedalam standar mutu dari bakso ikan yaitu SNI 7266:2014. Nilai organoleptik dengan uji hedonik diperoleh kenampakan 3.225, tekstur 3.35, aroma 3.2 dan rasa 3.3.

\section{DAFTAR PUSTAKA}

[1] Manurung, D. C., U. Pato, E. Rossi. 2017. Karakteristik kimia dan mutu sensori bakso ikan patin dengan penggunaan tepung bonggol pisang dan tapioka. Jom FAPERTA. Vol. 4, No. 1, Hal. 1-15

[2] Ibrahim, H. M. 2015. Chemical composition, minerals content, amino acids biovailability and sensory and properties of meat and fish balls containing fish fish protein isolate. International Journal of Current Microbialogy and Applied Sciences. Vol. 4, No. 4, Hal. 917-933

[3] Aziza, T., D. R. Affandi, G.J. Manuhara. 2015. Bakso ikan tongkol (Euthynnus affinis) dengan filler tepung gembili sebagai fortifikan inulin. Jurnal Teknologi Hasil Pertanian. Vol. VIII, No. 2, Hal. 77-83

[4] Fauziyah, A dan V. Indrawati. 2017. Pengaruh jumlah tepung sagu (Metroxylon sago rottb) dan jumlah bayam (Amaranthus Spp) terhadap sifat organoleptik bakso ikan gabus bayam. $E$ journal Boga. Vol. 5, No. 3, Hal. 1-10

[5] Nurlaila, A. Sukainah, Amiruddin. 2016. Pengembangan produk sosis fungsional berbahan dasar ikan tenggiri (Scomberomorus sp.) dan tepung daun kelor. Jurnal Pendidikan Teknologi pertanian. Vol. 2, Hal. 105-113

[6] Prihati, D. R. 2015. Pengaruh ekstrak daun kelor terhadap berat badan dan panjang badan anak tikus galur wistar. INFOKES. Vol. 5, No. 2, Hal. 15-22

[7] Aminah, S., T. Ramadhan, M. Yanis. 2015. Kandungan nutrisi dan sifat fungsional tanaman kelor (Moringa oleifera). Bulentin Pertanian Perkotaan. Vol. 5, No. 2, Hal. 35-44

[8] Purukan, O. P. M., C. F. Mamuaja, L. C. Mandey, L. P. Mamahit. 2013. Pengaruh penambahan bubur wortel (Daucus carrota) dan tepung tapioka terhadap sifat fisikokimia dan sensoris bakso ikan gabus (Ophiocephalus striatus). Fakultas Pertanian Universitas Sam Ratulangi

[9] Tahir, M., N. Hikmah, Rahmawati. 2016. Analisa kandungan vitamin $\mathrm{c}$ dan $\beta$ karoten dalam daun kelor (Moringa oleifera Lam) dengan metode spektrofotometri UV-VIS. Jurnal Fitofarmaka Indonesia. Vol. 3, No. 1, Hal. 135-140

[10] Meiliana, Roekistiningsih, E. Sutjiati. 2014. Pengaruh proses pengolahan daun singkong (Manihot esculenta Crantz) dengan berbagai perlakuan terhadap kadar $\beta$-karoten. Indonesian Journal of Human Nutrition. Vol. 1, No. 1, Hal. 2334

[11] Patang. 2014. Analisis tingkat kesegaran ikan layang (Decapterus $s p$ ) pada tempat pelelangan ikan Rajawali Kota Makassar. Jurnal Agrisistem. Vol. 10, No. 1, Hal. 34-39

[12] Zakaria, A. Tamrin, Nursalim, Irmayana. 2015. Pengaruh perlakuan blanching terhadap kadar $\beta$-karoten pada pembuatan tepung daun kelor (Moringa oleifera). Media Gizi Pangan. Vol. XIX, No. 1, Hal. 23-28

[13] Asmidar, Syahrul dan N. I. Sari. 2015. Pengaruh pemberian pewarna alami terhadap mutu bakso ikan patin (Pangasius hypopthalamus) selama penyimpanan pada suhu dingin $\left( \pm 5^{\circ} \mathrm{C}\right)$. JOM.

[14] Gross, Jean. 1991. Pigmens in Vegetables Chlorophylls and Carotenoids.Springer Science+Business Media. New York 
[15] Risfaheri, 2012. Diversifikasi produk lada (Piper nigrum) untuk peningkatan nilai tambah. Buletin Teknologi Pascapanen Pertanian. Vol. 8, No. 1, Hal. 15-26

[16] Zakaria, S., V. D. V. Febriani. 2011. Daya terima dan analisa komposisi gizi pada cookies dan brownis kukus pandan dengan substitusi tepung daun kelor (Moringa oleifera Lamk). Media Pangan Gizi. Vol. XII, No. 2, Hal. 11-19

[17] Moviana, R. 2015. Pembuatan nugget dengan penambahan daun kelor sebagai makanan alternatif makanan tinggi zat besi. Jurnal Kesehatan Umus Brebes. Vol. 1, No. 1, Hal. 96-107

[18] Rahmawati, P. S dan A. C. Adi. 2016. Daya terima dan zat gizi permen jeli dengan penambahan bubuk daun kelor (Moringa oleifera). Media Gizi Indonesia. Vol. 11, No. 1, Hal. 86-93

[19] Ilona, A. D dan R. Ismawati. 2015. Pengaruh penambahan ekstrak daun kelor (Moringa oleifera) dan waktu inkubasi terhadap sifat organoleptik yoghurt. E-Journal Boga. Vol. 4, No. 3, Hal. 151-159

[20] Hastuti, S., S. Suryawati dan I. Maflahah. 2015. Pengujian sensoris nugget ayam fortifikasi daun kelor. AGROINTEK. Vol. 9, No. 1, No. 71-75

[21] Sundari, D., Almasyhuri dan A. Lamid. 2015. Pengaruh proses pemasakan terhadap komposisi zat gizi bahan pangan sumber protein. Media Litbangkes. Vol. 25, No. 4, Hal. 235-242

[22] Agus, R.R. dan R. Ismawati. 2018. Pengaruh substitusi ubi jalar kuning, isolate protein kedelai dan tepung daun kelor terhadap kandungan gizi serta daya terima mi instan. Media Gizi Indonesia. 13(2):108-116 Nurlaila et al.(2016)

[23] SNI 7266:2014. www.bsn.go.id (diakses 3 Januari 2019)
[24] Keputusan Kepala Badan Pengawasan Obat dan Makanan RI Nomor HK.00.05.23.3644

[25] Kurniawati, I., M. Fitriyya dan Wijayanti.2018. Karakteristik tepung daun kelor dengan metode pengeringan sinar matahari. Prosiding Seminar Nasional Unimus. Vol. 1, Hal. 238-243 